\title{
Feed Intake and Growth Performance of Jersey Calves in Maize Stover Silage based Total Mixed Ration
}

\author{
Geberemariyam T., Getu K., Mulugeta W., Dereje F., Aeimro K., Mesfin D., Betlehem M and Endale Y. \\ Ethiopian Institute of Agricultural Research (EIAR), Holeta Agricultural Research Center, P.O. Box 31, Holeta, \\ Ethiopia
}

\begin{abstract}
A total of eighteen post weaned female Jersey calves (weighing, $72 \pm 1.33 \mathrm{~kg}$, mean $\pm \mathrm{SE}$ ) selected from Adeaberga dairy farm were randomly assigned in to two sample T-test each having nine calves. Calves in the first group were offered natural pasture hay and concentrate mixture separately (T1) whereas calves in the second group received dual purpose green maize stover silage based total mixed ration (TMR). The experiment took 180 and 7 days of feeding trial and digestibility trail respectively. The daily dry matter intake of calves fed T2 $(5.41 \mathrm{~kg})$ was higher $(\mathrm{p}<0.05)$ than calves receiving T1 $(4.64 \mathrm{~kg})$. Calves fed T2 have higher $(\mathrm{P}<0.05)$ apparent dry matter digestibility than calves fed $\mathrm{T} 1$ diets. Feed conversion ratio of the calves was not affected $(\mathrm{P}>0.05)$ by diets but average daily weight gain of calves in $\mathrm{T} 2(530 \mathrm{~g})$ was higher $(\mathrm{P}<0.05)$ than in $\mathrm{T} 1(450 \mathrm{~g})$. It can be said that the growth performance of calves fed the dual purpose green maize Stover silage based total mixed ration diet was superior than calves fed natural pasture hay and concentrate mixture following the conventional feeding practice. Investigate the comparative advantages of using maize crop for dual purposes (food \& feed) than as a food for human alone considering both biological responses and economic returns that arises thereof.
\end{abstract}

Keywords: Body weight gain, Digestibility, Intake, Maize Stover silage, Total mixed ration

DOI: $10.7176 / \mathrm{JBAH} / 10-17-02$

Publication date:September $30^{\text {th }} 2020$

\section{Introduction}

Major constraint to livestock production in Ethiopia is feeds and the art of feeding. Cattle are mainly fed on natural pasture hay and crop residues (Kitaba and Tamir 2007). Associated to increased human population and urbanization the need for crop cultivable land is putting pressure on the availability and cost of these conventional basal feed resources. To mitigate the problem it would be necessary to look into such alternative feed resources as dual purpose maize crop that can easily be integrated to the existing crop-livestock farming systems. Potentially, in Ethiopia, maize is planted on vast area of land (more than 2.4 million ha) according to recent, data from CSA, $(2018 / 19)$. The crop is the food staple for several million families, the majority of whom also rear dairy cattle and other livestock species (Thorne et al., 2002). An increased maturity at harvest affects an increased grain filling for human consumption, starch-to-NDF ratio and increased fraction of rumen by-pass starch in maize silages (Phipps et al., 2000). Inclusion of maize silage which is harvested at a more maturity stage ( $>350 \mathrm{~g} \mathrm{DM} / \mathrm{kg}$ fresh weight, dough stage) in the diet of dairy cows could be an option to increase the supply of starch and rumen by-pass starch. Moreover, a related study in the near past indicated that maize silage harvesting at dough stage of the grain results higher yields of dry matter, starch and energy (Zom et al., 2012). Therefore, increasing maturity may also contribute to an increased self-sufficiency rate for feed and hence reduce the farm purchases of feeds and forage, and the food-for-feed competition. In spite of the fact that whole crop maize silage is a major forage component in the ration of dairy cows, elsewhere outside Ethiopia, its utilization as a silage crop for dairy cattle feeding under local conditions is only limited to some government organizations (universities and research institution). As part of a solution to the problem a research project has been planned to use the green maize Stover for silage making at some later stage of grain maturity (i.e., after the grain was being harvested at dough stage with the assumption that the remaining grain moisture removed with sun drying for proper storage and use as a grain for human consumption). This research study being an innovative approach proposed to evaluate and thereby improve the potential contribution of maize as food-feed to the livelihoods of dairy producers at farm level in Ethiopia.

\section{Materials and Methods \\ Description of the study area}

The study was conducted at Adeaberga dairy farm, which is under Holeta agricultural research center, Ethiopia. The farm is located in the central highlands of Ethiopia at $9^{0} 16^{\prime} \mathrm{N}$ latitude and $38^{0} 23^{\prime} \mathrm{E}$ longitude, $70 \mathrm{~km}$ West of Addis Ababa and $35 \mathrm{~km}$ North West of Holeta on the main road to Muger. It lies at an altitude of 2500 meters above sea levels. It is characterized by cool sub-tropical climate with the mean annual temperature and rainfall of $18^{\circ} \mathrm{C}$ and $1225 \mathrm{~mm}$, respectively.

Experimental animals selection, design and calves management

A total of eighteen post weaned calves weighing $72 \pm 1.33 \mathrm{~kg}$ (mean $\pm \mathrm{SE}$ ) were selected from the farm and 
randomly assigned to the treatment diets using two sample T-test with eight calves per treatment. The calves were drenched with broad spectrum anti-helminthic (Albendazole $2500 \mathrm{mg}$ ) prior to the commencement of the feeding trial according to the manufacturer's prescription. Calves were kept in a well-ventilated barn with concrete floor, one sided wall and corrugated iron roof to protect from rain. The house had appropriate drainage slope and gutter for urine removal and stall feeding inside the rearing shed. Approximate metabolizable energy and crude protein requirements of the calves were derived from NRC, (2001) recommendations. The calves were allowed to exercise from 8:00 PM to 8:30 PM to maintain previous exercise practice.

\section{Experimental feed preparations and feeding management}

Dual purpose maize (food-feed) was planted following on station recommended planting and agronomic practices. Harvesting was made at some stage of grain maturity (dough stage) when residual moisture and soluble sugar is left for silage fermentation and after the cobs have been already removed for use as food for human consumption. The partially green maize Stover (35\% DM) was subjected to chopping (3-5 cm in length) and ensiled in the above ground silo of dimensions LxWxDepth in the presence of molasses additive added at the rate of 3\% on DM basis. The Stover was kept tight to ferment inside the silo for 45 days during the dry season (from December $15 / 2016$ to January 30/2017) up until the start of the feeding trial.

\section{Table 1: - Proportion of feed ingredients in the dietary treatments (DM basis)}

\begin{tabular}{llc}
\hline Feed & \multicolumn{2}{c}{ Treatment groups } \\
\cline { 2 - 3 } & $\mathrm{T} 1$ & $\mathrm{~T} 2$ \\
Hay & 50 & 0 \\
Maize Stover silage & 0 & 50 \\
Wheat bran & 19 & 19 \\
Cotton seed cake & 10 & 10 \\
Noug seed cake & 8 & 8 \\
Molasses & 12 & 12 \\
Salt & 1 & 1 \\
\hline
\end{tabular}

$\mathrm{T} 1=50 \%$ natural pasture hay ad libitum $+50 \%$ concentrate mixture, $\mathrm{T} 2=\mathrm{TMR}(50 \% \mathrm{MS}: 50 \% \mathrm{CM})$.

\section{Feeding trial}

The initial body weights of weaned Jersey calves were measured by using fixed cattle weighing. The feeding trial was carried out for a total of 180 days. During the feeding trial period daily feed and nutrient intake and fortnightly live weight changes were measured. Natural pasture hay for T1 group and maize stover silage based TMR for T2 group were offered ad-libitum while the concentrate mixture for T1 group was offered twice a day at 6.00 AM and 2:00 PM. Feed offer per each dietary treatment was periodically subjected to revision with changes in live body weight. Water was provided free of any choice. The amount of daily feed consumed and refused per calve was recorded and used to calculate feed and nutrient intake of the calves. Before offering the morning meal, all weaned calves were individually weighed at every 15 days. The average daily body weight gain of the calves was calculated by dividing the difference of final and initial live weight to experimental duration i.e. 180 days.

\section{Digestibility trial}

At the end of the experiment, faeces from each animal were collected using the total faecal collection method, measured and recorded for seven consecutive days. To avoid cross contaminations with urine farm personnel were assigned to scoop the faeces into a plastic bucket upon defecation around the clock. Faecal sample for laboratory feed chemical analysis was obtained through direct rectal grabbing's at six time intervals a day. The faecal samples were stored in deep freezer $\left(-20^{\circ} \mathrm{C}\right)$ until ready for subsequent lab analysis.

\section{Chemical analysis}

Maize stover silage, natural pastures hay, TMR feed and faecal samples were dried at $55{ }^{\circ} \mathrm{C}$ for $48 \mathrm{~h}$.

The dried samples were milled by using a Wiley mill pass through 1-mm sieve size. Feed and faecal samples DM, Ash and N were analysed (AOAC, 1990), ADF, permanganate lignin and NDF were analysed (Van Soest and Robertson, 1985), in vitro organic matter digestibility were analysed by using two stage procedures of Tilley and Terry (1963), metabolizable energy was estimated from DOMD as ME $(\mathrm{MJ} / \mathrm{kg})=0.16 *$ in vitro organic matter digestibility (McDonald et al. 2002)

\section{Statistical analysis}

The data was subjected to analyse by using a single factor ANOVA through SAS procedure (SAS, 2002). Tukey mean separation test at 5\% level of significance was used. 


\section{Results and Discussion}

\section{Chemical composition of feeds}

The chemical composition of maize Stover silage based mixed ration and the feed ingredients is presented in Table (2). Among feed ingredients the two protein sources (Cotton seed cake \&Noug seed cake have the highest CP and the lowest IVDOMD and NDF compared to the energy source (wheat bran). In the current finding, the DM, ash and CP contents of maize stover silage based mixed ration is comparable with other findings (Habtie et al., 2019 and Geberemariyam et al., 2020) while the fiber fractions (NDF, ADF and lignin) were higher than the values reported by other researchers (Pachauri et al., 2010 and Arto et al., 2014). The possible reason for the variation of the current result and the previous reports could be related to difference in chemical compositions and proportion of the ingredients used in the total mixed ration. The current finding is consistent with the study of Rajamma (2014), Buddanoil et al. (2017) and Habtie et al., (2020) who reported maize Stover use as roughage source in TMR could increase nutritive value of the diet.

Table 2:-Chemical composition (g/kg DM) of the ingredients and total mixed ration

\begin{tabular}{lllllllll}
\hline & DM & Ash & CP & NDF & ADF & Lignin & IVOMD & $\begin{array}{l}\text { ME } \\
\text { (MJ/KgDM) }\end{array}$ \\
\hline Hay & 92.12 & 6.52 & 5.45 & 62.24 & 40.89 & 7.50 & 50.41 & 8.07 \\
Maize Stover silage & 36.89 & 7.21 & 5.92 & 64.03 & 37.67 & 8.65 & 59.56 & 9.53 \\
Wheat bran & 88.82 & 5.14 & 16.50 & 48.03 & 18.89 & 4.43 & 69.89 & 11.18 \\
Cotton seed cake & 91.20 & 5.80 & 27.00 & 43.70 & 23.90 & 5.30 & 62.90 & 10.10 \\
Noug seed cake & 90.89 & 8.10 & 33.60 & 41.35 & 30.19 & 8.50 & 63.40 & 10.14 \\
Concentrate mixture & 90.24 & 5.49 & 20.87 & 42.23 & 14.88 & 5.24 & 67.02 & 10.72 \\
Total mixed ration & 62.07 & 8.12 & 12.88 & 54.15 & 25.65 & 6.28 & 62.89 & 10.08 \\
\hline
\end{tabular}

Dry matter (DM), Crude protein (CP); Neutral detergent fibre (NDF); Acid detergent fibre (ADF); Acid detergent lignin (ADL); Invitro organic matter digestibility (IVOMD) and Metabolizable energy (ME)

\section{Dry matter and nutrient intake}

The average DM and nutrient intakes of the experimental calves are presented in Table 3. There was significant $(\mathrm{P}<0.05)$ difference in average total DM and nutrient intakes among experimental calves. In the current finding partial inclusion of green maize Stover in the total ration of dairy calves noted to have increased feed and nutrient intake is in agreement with the previous finding of Phipps et al., (2000) and Habtie et al., (2020). The higher total $\mathrm{DM}, \mathrm{OM}$ and $\mathrm{CP}$ intake in $\mathrm{T} 2$ was due to the higher DM, OM and CP concentration in the diets.

Table 3:- Average dry matter and nutrient intake of calves (Kg/ calves/day)

\begin{tabular}{llcll}
\hline Intake & \multicolumn{2}{c}{ Treatments } & SEM & P-value \\
\cline { 2 - 3 } Hay & $\mathrm{T} 1$ & $\mathrm{~T} 2$ & - & - \\
Maize Stover silage & 2.34 & - & - & - \\
Concentrate mixture & - & 2.72 & 0.07 & 0.05 \\
Total DM & $2.27^{\mathrm{b}}$ & $2.66^{\mathrm{a}}$ & 0.21 & 0.05 \\
Organic matter & $4.64^{\mathrm{b}}$ & $5.41^{\mathrm{a}}$ & 0.4 & 0.01 \\
Crude protein & $4.34^{\mathrm{b}}$ & $4.98^{\mathrm{a}}$ & 0.05 & 0.05 \\
NDF & $0.65^{\mathrm{b}}$ & $0.74^{\mathrm{a}}$ & 0.18 & 0.000 \\
ADF & $2.42^{\mathrm{a}}$ & $2.88^{\mathrm{b}}$ & 0.14 & 0.001 \\
\hline
\end{tabular}

${ }^{\mathrm{ab}}$ Means in each row with different letters have a significance difference, $\mathrm{SEM}=$ standard error of the mean , T1 = $50 \%$ natural pasture hay ad libitum $+50 \%$ concentrate mixture, T2 $=$ TMR $(50 \%$ maize Stover silage: $50 \%$ concentrate mixture).

\section{Apparent digestibility of dry matter and nutrient}

The apparent digestibility of DM, OM, CP, NDF and ADF were significantly $(\mathrm{P}<0.05)$ affected by dietary treatments (Table 4). The calves receiving the intervention diet (T2) digesting 5.80\% CP, 4.74\% NDF and 9.92\% ADF more than calves on the control diet. The higher apparent digestibility of CP, NDF and ADF in T2 observed in the present study is in agreement with the finding of Habtie et al., (2020) and Rajamma (2014) who suggested that utilization of green maize stover silage made from maize crop harvested at late grain maturity could increase nutritive value and digestibility of the feed 
Table 4:- Apparent dry matter and nutrient digestibility of calves fed different diet.

\begin{tabular}{lllll}
\hline Apparent digestibility (\%) & T1 & T2 & SEM & P value \\
\hline DM & $58.64^{\mathrm{b}}$ & $64.03^{\mathrm{a}}$ & 2.68 & 0.05 \\
OM & $56.26^{\mathrm{b}}$ & $62.81^{\mathrm{a}}$ & 2.14 & 0.05 \\
CP & $60.76^{\mathrm{b}}$ & $64.50^{\mathrm{a}}$ & 2.33 & 0.05 \\
NDF & $64.98^{\mathrm{b}}$ & $68.22^{\mathrm{a}}$ & 1.77 & 0.01 \\
ADF & $50.12^{\mathrm{b}}$ & $55.64^{\mathrm{a}}$ & 1.79 & 0.05 \\
\hline
\end{tabular}

Means in each row with different letters have a significance difference, $\mathrm{SEM}=$ standard error of mean, $\mathrm{DM}=\mathrm{Dry}$ matter, $\mathrm{OM}=$ Organic matter, $\mathrm{CP}=$ Crude protein, $\mathrm{NDF}=$ Neutral detergent fiber, $\mathrm{ADF}=$ Acid detergent fiber, $\mathrm{T} 1$ $=50 \%$ natural pasture hay ad libitum $+50 \%$ concentrate mixture, $\mathrm{T} 2=\mathrm{TMR}(50 \% \mathrm{MS}: 50 \% \mathrm{CM})$.

\section{Body weight gain and feed conversion efficiency}

The growth performances, feed conversion ratio and crude protein utilization efficiencies of the heifers is described in Table 5. The average daily body weight gain of calves fed T2 was higher $(\mathrm{P}<0.05)$ than calves fed T1. However, feed conversion ratio and protein conversion efficiency was not affected by the dietary treatments $(\mathrm{P}>0.05)$. The calves receiving maize stover silage based total mixed ration was gained $80 \mathrm{~g} /$ day body weight over than calves in the control group. The higher daily weight gain in the total mixed ration observed in the current study is consistence with the finding of Shiriyan et al. (2011) and Geberemariyam etal (2020) all of whom have found higher daily body weight gain for animals maintained on TMR based diets than those fed on concentrate and roughage following conventional feeding practices (i.e., the roughage and the concentrates were fed separately). Positive growth responses of calves in the intervention diet might be related with the higher dry matter and nutrient intake and the higher apparent digestibility of acid detergent fiber and neutral detergent fiber.

Table 5:- Growth performance and feed conversion ratio of experimental calves fed with either the control or TMR based diets

\begin{tabular}{|c|c|c|c|c|}
\hline \multirow[b]{2}{*}{ Growth Parameters } & \multicolumn{2}{|c|}{ Treatments } & \multirow[t]{2}{*}{ SEM } & \multirow[t]{2}{*}{$P$ value } \\
\hline & $\mathrm{T} 1$ & $\mathrm{~T} 2$ & & \\
\hline Initial live weight $(\mathrm{kg})$ & 72 & 72 & 1.33 & NS \\
\hline Final live weight $(\mathrm{kg})$ & $153.84^{\mathrm{b}}$ & $167.31^{\mathrm{a}}$ & 2.51 & 0.05 \\
\hline Average live weight changes $(\mathrm{kg})$ & $81.84^{\mathrm{b}}$ & $95.42^{\mathrm{a}}$ & 3.68 & 0.05 \\
\hline Average daily body weight gain $(\mathrm{kg})$ & $0.45^{\mathrm{b}}$ & $0.53^{\mathrm{a}}$ & 0.14 & 0.01 \\
\hline Dry matter intake $\left(\mathrm{kg} \mathrm{day}^{-1}\right)$ & $4.61^{b}$ & $5.38^{\mathrm{a}}$ & 0.21 & 0.05 \\
\hline Crude protein intake $(\mathrm{kg})$ & $0.65^{b}$ & $0.74^{\mathrm{a}}$ & 0.05 & 0.05 \\
\hline Feed conversion ratio (DMI/DWG) & 10.24 & 10.15 & 1.01 & NS \\
\hline Protein efficiency & 0.69 & 0.71 & 0.02 & NS \\
\hline
\end{tabular}

${ }^{a b}$ Means within a row with different letters have a significance difference, $\mathrm{Ns}=$ Non significance; $\mathrm{SEM}=$ standard error of mean, $\mathrm{T} 1=50 \%$ natural pasture hay ad libitum $+50 \%$ concentrate mixture, $\mathrm{T} 2=\mathrm{TMR}(50 \% \mathrm{MS}: 50 \%$ $\mathrm{CM}), \mathrm{DMI}=$ dry matter intake, $\mathrm{DWG}=$ daily weight gain

As can be seen from figure one below those calves fed the intervention diet (T2) consistently gained more weight compared to calves receiving the control diet (T1) throughout the growth period.

Figure 1: Trends of calves' daily body weight gain during the experiment.

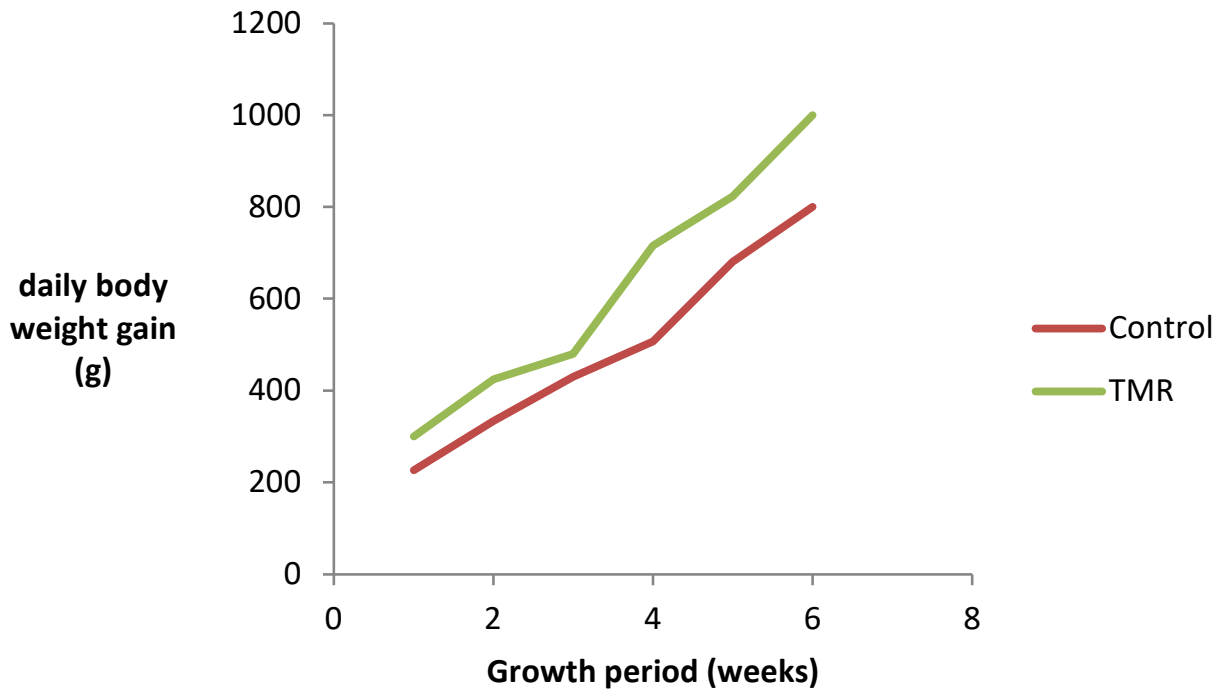




\section{Conclusions and Recommendations}

It can be concluded that the growth performance of calves fed dual purpose green maize Stover silage based total mixed ration diet were superior than calves fed natural pasture and concentrate mixture separately. Raising calves by using dual purpose maize Stover silage based total mixed ration can be recommended for wider use at field levels once comparative advantage of using maize crop for food-feed rather than for food alone is verified with further study under actual farm conditions.

\section{Acknowledgment}

The authors would like to thank Ethiopian Institute of Agricultural Research for financial support.

\section{References}

AOAC. 2005. Official Methods of Analysis, $18^{\text {th }}$ edn. Association of Official Analytical Chemists, Arlington, Vrginia, USA.

CSA (Central Statistical Agency), 2018/19. The federal democratic republic of Ethiopia central statistical agency agricultural sample survey 2018/19 (2011 E.C.).Volume I. Report on area and production of major crops. Statistical bullet in 589. Addis Ababa, Ethiopia.

Geberemariyam Terefe, Ajebu Nurfeta, Getnet Assefa and Getu Kitaw: 2020. Total Mixed Ration and Conventional Feeding for Post Weaned Jersey Calves. Proceeding of the $7^{\text {th }}$ Annual National Reviews Workshop on Results of Livestock Research Holeta Agricultural Research Center, Ethiopia.

Habte Abebaye, Ashenafi Mengistu, Berhan Tamir, Getnet Assefa and Fekede Feyissa.2020.Effect of maize silage and concentrates fed separately or as total mixed ration (TMR) on milk yield of Jersey cows. Livestock Research for Rural Development.32 (2).

Kitaba, A. and Tamir, B., 2007. Effect of harvesting stage and nutrient levels on nutritive values of natural pasture in central highlands of Ethiopia. Agricultura Tropica et Subtropica, 40(1), 7-12.

McDonald, P.R., Edwards, A., Greenhalgh, T.F.D. and Morgan, C.A. 2002.Evaluation of feeds.Animals Nutrition $5^{\text {th }}$ edition. pp.221-228.

National Research Council.2001. Nutrient Requirements of Dairy Cattle. 7th rev.ed. National Academic Sciences. Washington, DC.

Pachauri S.K., Singh S.K. and Mudgal Vishal. 2010. Effect of Feeding Wheat Straw and Urea Ammoniated Wheat Straw Based Total Mixed Rations on the performance of Female Crossbred Calves. Indian Journal Animal Nutrition. 27 (1):73-76.

Raja Kishore Konka, Srinivas Kumar Dhulipalla, Venkata Ramana Jampala, Ravi Arunachalam Sudhakara and Reddy Puchhalapalli .2013.In situ Degradation Kinetics of Crop Residue Based Complete Rations in Murrah Buffalo Bulls. Journal ofAdvanced Veterinary Research 3: 142-146.

SAS (Statistical Analysis System). 2002. SAS Institute Inc, NC, USA.

Tilley J.M.A. and Terry R.A. 1963. A two stage method for the in vitro digestion of forage crops. Journal Britannia Grassland Society.18: 104-111.

Thorne P. J., Thornton P. K., Kruska R., Reynolds L., Waddington, S. R., Rutherford A. S. and Othero A. N. (2002). Maize as food, feed and fertilizer in intensifying crop- livestock systems in East and southern Africa: An ex ante impact assessment of technology interventions to improve smallholder welfare. ILRI Impact Assessment Series 11. International Livestock Research Institute, Nairobi, Kenya, 123 p.

Van Soest, P.J. and Robertson J.B. (1985). Analysis of Forages and Fibrous Foods a Laboratory Manual for Animal Science. Cornell University, Ithaca, NY.

Zom, R.L.G., Bannink, A., Goselink, R.M.A., 2012. Effect of increased maturity of silage maize at harvest on conservation, dairy cow performance and methane emission.WageningenUR Livestock Research, Wageningen, The Nederlands 